\title{
Influence of arbuscular mycorrhizal fungi on growth and essen- tial oil composition in Ocimum basilicum var. Genovese
}

\author{
Copetta Andrea $^{1}$, Guido Lingua ${ }^{1}$, Laura Bardi ${ }^{2}$, Giorgio Masoero ${ }^{2}$ and Graziella \\ BERTA ${ }^{1, *}$ \\ ${ }^{1}$ Università del Piemonte Orientale “A. Avogadro”, Di.S.A.V., via Bellini 25/G, 15100, Alessandria, Italy. \\ ${ }^{2}$ Istituto Sperimentale per la Nutrizione delle Piante, Ente C.R.A., Torino, Italy.
}

\begin{abstract}
Sweet basil is characterized by its essential oils, synthesized and stored in glandular hairs. Arbuscular mycorrhizal (AM) fungi colonize the root of most terrestrial plants, forming a very common symbiosis. In the present paper, the effects induced by three arbuscular mycorrhizal fungi (Glomus mosseae or Gigaspora margarita or Gigaspora rosea) on shoot growth and essential oil production of Ocimum basilicum var. Genovese were evaluated. Gi. rosea significantly increased internode number and decreased internode distance in comparison with control plants and the other fungal treatments. Furthermore, Gi. margarita and Gi. rosea modified essential oil content analyzed semi-quantitatively.
\end{abstract}

Key words: AM fungi, essential oil, internodes, sweet basil.

\section{INTRODUCTION}

Ocimum basilicum L. is a Mediterranean aromatic species that produces characteristic flavours and fragrances used in pharmaceutical, cosmetic, food and industrial products. Several authors have reported antioxidant, insecticidal, nematocidal, antifungal and antibacterial activity of basil essential oils (SANGWAN et al. 1990; Wan et al. 1998; Griffin et al. 1999; Dorman et al. 2000; Javanmardi et al. 2003; Pascual-Villalobos and Ballesta-Acosta 2003). Essential oils are synthesized and stored in peltate glands especially; these are leaf structures responsible for oil production (GANG et al. 2001). Recent studies demonstrated that arbuscular mycorrhizal (AM) fungi, root symbionts that improve plant health and mineral nutrition (SMith and ReAD 1997), can modify the number of peltate trichomes within basil and oregano leaves, and increase the concentration of some essential oils (COPETTA et al. 2006a; KHAOSAAD et al. 2006). Such modifications of the essential oil profile was confirmed by both NIR (Near Infra Red) Spectroscopy and Electronic Nose analyses (CopetTA et al. 2006b).

\footnotetext{
* Corresponding author: phone: +39 0131 360232; fax +390131 360390; e-mail: graziella.berta@unipmn.it
}

Five different chemotypes of $O$. basilicum $\mathrm{L}$ have been identified depending on the relative abundance of aromatic compounds (GRAYER et al. 1996). In O. basilicum var. Genovese the most abundant essential oils are eugenol and linalool, but this variety produces others phenyl-propanoids and terpenoids in different proportion.

The aim of the present work was to better characterize the effects of three AM fungi on the aromatic profile of $O$. basilicum var. Genovese, by means of chemical analyses concerning six, previously not considered, essential oils. In addition, also the impact of AM colonization on shoot morphology was considered.

\section{MATERIALS AND METHODS}

Sweet basil (Ocimum basilicum L., var. Genovese) seeds (Zorzi, Padova, Italy) were surface sterilized (GAMALERO et al. 2004) and pre-germinated on moist sterile filter paper at $24^{\circ} \mathrm{C}$ in the dark for 3 days. They were then transplanted into plastic pots with $100 \mathrm{ml}$ quartz sand (diameter 2-3 $\mathrm{mm}$ ) on the bottom and with $600 \mathrm{ml}$ substrate made of 1:1 fine quartz sand (0.6-1.2 mm):vermiculite (Punto Elle, Turin, Italy). Culture substrates were sterilized at $200^{\circ} \mathrm{C}$ for $2 \mathrm{~h}$. Four treatments were considered: control plants without mycorrhizae (C), plants inoculated with Glomus 
mosseae (Nicolson \& Gerdemann) Gerd. \& Trappe BEG 12 (G.m) or Gigaspora margarita Becker \& Halle BEG 34 (Gi.ma) or Gigaspora rosea Nicolson \& Schenck BEG 9 (Gi.r) plants. Inoculation of AM fungi was obtained by incorporating $30 \%(\mathrm{v} / \mathrm{v})$ of the inoculum-quartz sand mix (BIORIZE) into the growth substrate. A total of 28 plants per treatment were prepared. Plants were kept in a growth chamber with a 16/18 h light/dark photoperiod, $26 / 22^{\circ} \mathrm{C}$ light/dark thermoperiod, $150 \mu \mathrm{Em}^{-2} \mathrm{~s}^{-2}$ light irradiance at pot height (Sylvania 58W), and watered to saturation three times per week with a modified Long Ashton nutrient solution containing $32 \mu \mathrm{M}$ phosphate (TrotтA et al. 1996). Plants were harvested at 21, 42 and 63 days from the sowing and processed as described below.

Root systems were fixed in $70 \%$ ethanol and stored at $4^{\circ} \mathrm{C}$. Mycorrhizal colonization was estimated according to Trouvelot et al. (1986). Shoot length, node number, and the internode distances were determined.

After 42 and 63 days of growth, five plants per treatment were used for the chemical evaluation of essential oil content. All leaves were collected, weighed and the essential oils extracted in $n$-hexane (Sigma) and analyzed according to Copetta et al. (2006a). Components were identified according to databases and quantified by comparison with certified standards for 12 oils ( $\alpha$-pinene, $\beta$-myrcene, limonene, eucalyptol, linalool, camphor, $\alpha$-terpineol, eugenol, caryophyllene, menthol, 4-allyl anisole, and skatol). Therefore, the analyses were semi-quantitative. Quantitative results for the 12 oils used as standard are published in CopetTA et al. (2006a).

Mycorrhizal, shoot, leaf and essential oil data were statistically analysed by ANOVA followed by Fisher's PSLD test, with cut-off significance at $\mathrm{p} \leq 0.05$.

\section{RESULTS}

The root system of basil was colonised in different ways by the three AM fungi (Fig. 1). Gi. margarita colonised less extensively basil root system than the other two fungi. Arbuscule density $(\mathrm{A} \%)$ decreased with time in G. mosseae plants, while it was similar to mycorrhizal colonization $(\mathrm{M} \%)$ in the roots of Gi. rosea and Gi. margarita samples. Control roots were not infected.

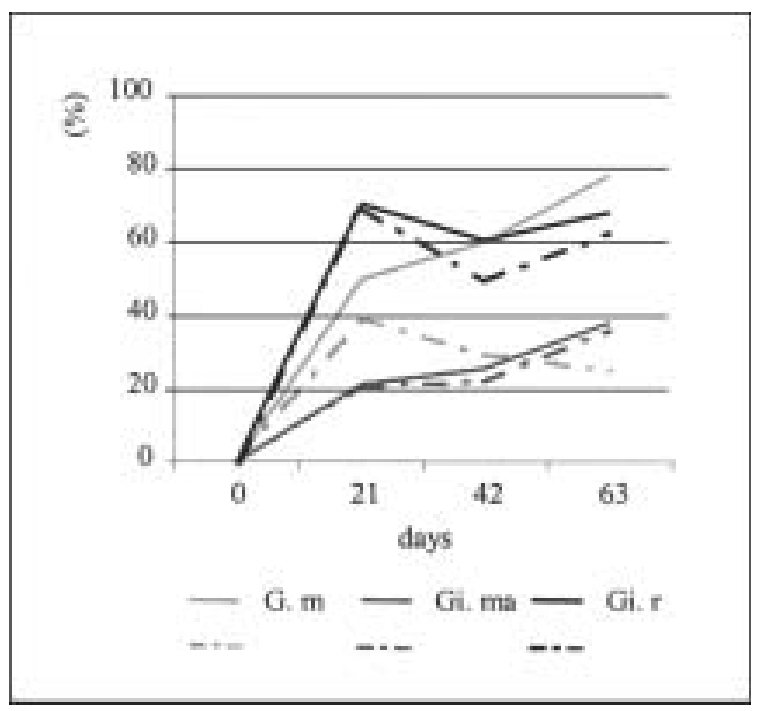

Fig. 1 - Mycorrhizal colonization (continuous lines) and arbuscular density (dotted lines) in the root systems, at the three harvests.

After 21 days of growth G. mosseae significantly increased the number of nodes, in comparison with the other three treatments (Table 1). After 63 days, Gi. rosea plants showed a significant increase of shoot length and number of nodes. Treatment with AM fungi also affected the distance of each node from the collar (i.e. the internode length) (Fig. 2): the distance between nodes and collar was often significantly lower in Gi. rosea plants than in the other treatments.

After 42 days of growth, no differences in essential oil could be observed between control and mycorrhizal plants or between the various fungal treatments (Table 2). At the last harvest, plants colonized by Gi. margarita showed a significant increased in the yield of methyl eugenol in com-

Table 1 — Shoot length and node number at the three harvests.

\begin{tabular}{|c|c|c|c|c|c|c|}
\hline & \multicolumn{3}{|c|}{ Shoot length $(\mathrm{cm})$} & \multicolumn{3}{|c|}{ Number of nodes } \\
\hline & 21st day & 42nd day & 63rd day & 21st day & 42nd day & 63rd day \\
\hline $\mathrm{C}$ & $4.2 \pm 0.3 \mathrm{ab}^{1}$ & $26.0 \pm 1.8 \mathrm{ab}$ & $46.9 \pm 1.7 \mathrm{a}$ & $1.2 \pm 0.2 \mathrm{a}$ & $4.9 \pm 0.1 \mathrm{ac}$ & $7.7 \pm 0.3 \mathrm{a}$ \\
\hline G. m & $4.9 \pm 0.6 \mathrm{a}$ & $27.6 \pm 2.2 \mathrm{a}$ & $48.5 \pm 2.2 \mathrm{a}$ & $1.8 \pm 0.2 \mathrm{~b}$ & $5.4 \pm 0.2 \mathrm{~b}$ & $8.2 \pm 0.3 a$ \\
\hline G. ma & $3.9 \pm 0.4 \mathrm{ab}$ & $23.0 \pm 1.6 \mathrm{~b}$ & $50.5 \pm 1.6 \mathrm{ab}$ & $1.0 \pm 0.0 \mathrm{a}$ & $4.8 \pm 0.1 \mathrm{a}$ & $8.1 \pm 0.2 \mathrm{a}$ \\
\hline G. r & $3.6 \pm 0.3 \mathrm{~b}$ & $26.9 \pm 1.4 \mathrm{ab}$ & $54.7 \pm 1.4 \mathrm{~b}$ & $1.0 \pm 0.0 \mathrm{a}$ & $5.2 \pm 0.1 \mathrm{bc}$ & $9.0 \pm 0.2 \mathrm{~b}$ \\
\hline
\end{tabular}

${ }^{1}$ Different letters indicate statistically significant differences $(\mathrm{p}<0.05)$ comparing treatments (along the columns of the table) 


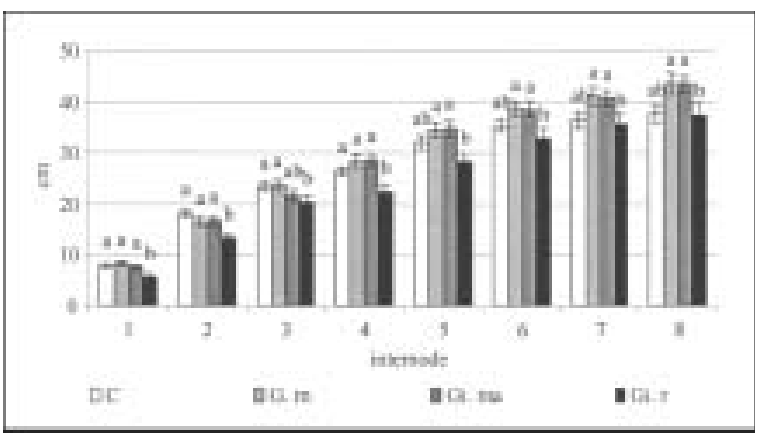

Fig. 2 - Distance between the collar and each leaf couple in basil plants inoculated with different fungal treatments. Different letters indicate statistically significant differences $(\mathrm{p}<0.05)$.

parison with all the other treatments, while those colonized by Gi. rosea increased bornil acetate content. In addition, plants colonized by Gi. margarita and Gi. rosea showed higher content in $\delta$-cadinene.

\section{DISCUSSION}

Recent works (COPETTA et al. 2006a; CopetTA et al. 2006b) proved the influence of mycorrhizal colonization on plant growth, glandular tricome distribution in basil leaf and essential oil production. Theses modifications are not due to increased $\mathrm{P}$ nutrition. In the above mentioned papers, growth and development of mycorrhizal and non-mycorrhizal basil were compared, and the effects of different AM fungi on plant growth are described. In particular, growth results showed that Gi. rosea increased shoot height; the present data show that such increase is also associated to decreased internode length. The latter is a desir- able trait because it enhances plant stability, therefore improving plant resistance to the wind and stem breaking (NICK 2000). Increased growth can be obtained by increasing either cell number or individual cell volumes. During most of their life cycle, plants exhibit indeterminate morphogenesis and grow predominantly by cell expansion. An extensive body of information demonstrate an intimate link between cortical microtubules and the preferential axis of growth. Hormones such as auxins, giberellins and abscissic acid can induce reorientation of microtubules (Nick 2000). Particularly, the giberellins (GAs) control stem elongation, internode length, leaf expansion and trichome development (DAviEs 1995; Vogler et al. 2003). Several studies (Dixon et al. 1988; ToReLli et al. 2000) showed that AM fungi can alter the profile of these hormones. These alterations can be responsible for variations in both shoot morphogenesis and production of peltate glands (COPETTA et al. 2006a), the responsible for oil production (GANG et al. 2001).

The cultivar Genovese showed the linalooleugenol profile, as observed also from MARITTO et al. (1996). Previous papers showed that after 63 days of growth, Gi. rosea significantly increased the concentration of camphor, $\alpha$-terpineol, and the total amount of essential oils, while plants treated with Gi. margarita had significantly decreased eucalyptol, linalool, eugenol content, and the total concentration of essential oils (COPETTA et al. 2006a). In this work, semiquantitative analyses did not detect any difference after 42 days of growth. At last harvest, semiquantitave chemical analyses showed differences in essential oil composition among treatments: while G. mosseae did not alter content of examined compounds relative to control plants, Gi. rosea and Gi. margarita sig-

Table 2 - Essential oil concentrations in O. basilicum leaves $(\mu \mathrm{g} / \mathrm{g})$ according to semi-quantitative chemical analyses.

\begin{tabular}{|c|c|c|c|c|c|}
\hline & & $\mathrm{C}$ & G.m & Gima & Gi.r \\
\hline \multirow{6}{*}{42 days } & Borneol & $3.32 \pm 1.00 \mathrm{a}^{1}$ & $2.38 \pm 0.96 \mathrm{a}$ & $3.15 \pm 0.68 \mathrm{a}$ & $2.46 \pm 0.95 \mathrm{a}$ \\
\hline & Bornil acetate & $1.53 \pm 0.70 \mathrm{a}$ & $1.25 \pm 0.62 \mathrm{a}$ & $1.43 \pm 0.27 \mathrm{a}$ & $1.12 \pm 0.48 \mathrm{a}$ \\
\hline & Elixene & $0.56 \pm 0.30 \mathrm{a}$ & $0.58 \pm 0.39 a$ & $1.23 \pm 0.52 \mathrm{a}$ & $0.60 \pm 0.46 \mathrm{a}$ \\
\hline & Methyl Eugenol & $8.02 \pm 4.57 \mathrm{a}$ & $10.11 \pm 5.61 \mathrm{a}$ & $13.79 \pm 7.17 \mathrm{a}$ & $19.07 \pm 7.18 \mathrm{a}$ \\
\hline & $\alpha$-Bergamotene & $17.25 \pm 5.01 \mathrm{a}$ & $17.05 \pm 3.89 a$ & $13.56 \pm 2.52 \mathrm{a}$ & $13.99 \pm 6.91 \mathrm{a}$ \\
\hline & $\delta$-Cadinene & $7.25 \pm 1.24 \mathrm{a}$ & $10.86 \pm 2.00 \mathrm{a}$ & $10.12 \pm 2.56 \mathrm{a}$ & $5.88 \pm 1.94 \mathrm{a}$ \\
\hline \multirow[t]{6}{*}{63 days } & Borneol & $3.81 \pm 1.52 \mathrm{a}$ & $2.65 \pm 1.17 \mathrm{a}$ & $3.39 \pm 1.65 \mathrm{a}$ & $2.07 \pm 0.62 \mathrm{a}$ \\
\hline & Bornil acetate & $1.66 \pm 0.53 \mathrm{a}$ & $0.78 \pm 0.23 \mathrm{a}$ & $2.26 \pm 0.75 \mathrm{ab}$ & $3.33 \pm 0.49 \mathrm{~b}$ \\
\hline & Elixene & $1.11 \pm 0.36 \mathrm{a}$ & $0.79 \pm 0.29 \mathrm{a}$ & $1.30 \pm 0.25 \mathrm{a}$ & $1.14 \pm 0.13 \mathrm{a}$ \\
\hline & Methyl Eugenol & $0.24 \pm 0.15 \mathrm{a}$ & $0.15 \pm 0.15 \mathrm{a}$ & $13.19 \pm 5.26 \mathrm{~b}$ & $1.00 \pm 0.27 \mathrm{a}$ \\
\hline & $\alpha$-Bergamotene & $14.90 \pm 4.38 \mathrm{a}$ & $8.87 \pm 2.50 \mathrm{a}$ & $20.05 \pm 5.27 \mathrm{a}$ & $17.36 \pm 4.20 \mathrm{a}$ \\
\hline & $\delta$-Cadinene & $6.57 \pm 0.77 \mathrm{a}$ & $7.10 \pm 1.11 \mathrm{a}$ & $21.60 \pm 2.99 \mathrm{~b}$ & $17.05 \pm 1.47 \mathrm{~b}$ \\
\hline
\end{tabular}

${ }^{1}$ Different letters indicate statistically significant differences $(\mathrm{p}<0.05)$ comparing treatments (along the lines of the table) 
nificantly increased bornil acetate and methyl eugenol respectively; both the Gigaspora species increased $\delta$-cadinene content.

MiELE et al. (2001) have shown that methyl eugenol concentration decreased with shoot length in $O$. basilicum. Similar results were obtained in our experiments, with the exception of the plants colonized by Gi. margarita. A O-methyltransferase catalyzed a specific methylation of eugenol for methyl eugenol production (WANG et al. 1997; LeWINSOHN et al. 2000). The activity of the enzyme decreases when plants grow (Miele et al. 2001). We assumed that in Gi. margarita plants the activity of $O$-methyltransferase did not decrease. In the other treatments, the decrease of methyl eugenol content followed the increase of eugenol content. Although methyl eugenol is approved for commercial use in food, in perfumes, creams and detergents, this compound is a carcinogenic phenylpropanoid (MIELE et al. 2001). However, intake of this compound with the human diet is usually considered to be very low (Miele et al. 2001). The use of AM fungi, increasing the speed of shoot growth, decreased the time and the production of methyl eugenol in O. basilicum var Genovese.

Results showed that different AM fungi can induce different effects very important in the same plant also for human health. These results are in agreement with NIR analyses and aromatic profiles obtained by EN in previous results by our group (COPETTA et al. 2006b).

\section{REFERENCES}

Copetta A., Lingua G., and Berta G., 2006a - Effects of three AM fungi on growth, distribution of glandular hairs and essential oil production in Ocimum basilicum L. var. Genovese. Mycorrhiza, 16: 485-494.

Copetta A., Lingua G., Berta G., Bardi L., and MaSOERo G., 2006b - Three arbuscular mycorrbizal fungi differently affect growth, distribution of glandular trichomes and essential oil composition, in $\mathrm{Oci}$ mum basilicum var. Genovese. Acta Horticulturae, 723: 151-156.

Davies P. J., 1995 — Plant Hormones: Physiology, Biochemistry and Molecular Biology. Kluwer Academic Publishers, Dordrecht, The Netherlands.

Dixon R. K., Garret, H. E., and Cox G. S., 1988 Cytokinins in the root pressure exudate of Citrus Jambhiri Lush. colonized by vesicular arbuscular mycorrbiza. Tree Physiology, 4: 9-18.

Dorman H. J. D., Figueiredo A. C., Barroso J. G., and Deans S. G., 2000 - In vitro evaluation of antioxidant activity of essential oils and their components. Flavour and Fragrance Journal, 15: 12-16.

Gamalero E., Trotta A., Massa N., Copetta A., MartinotTi M. G., and Berta G., 2004 - Impact of two fluorescent pseudomonads and an arbuscular mycorrbizal fungus on tomato plant growth, root architecture and P acquisition. Mycorrhiza, 14: 185 192.

Gang D. R., Wang J., Dudareva N., Hee Nam K., Simon J. E., Lewinsohn E., and Pichersky E., 2001 - An investigation of the storage and biosynthesis of phenylpropenes in sweet basil. Plant Physiology, 125: 539-555.

Grayer R. J., Kite G. C., Goldstone F. J., Bryan S. E., Paton A., and Putievsky E., 1996 - Infraspecific taxonomy and essential oil chemotypes in sweet basil, Ocimum basilicum. Phytochemistry, 43: 10331039.

Griffin S. G., Wyllie S. G., Markham J. L., and LEACH D. N., 1999 - The role of structure and molecular properties of terpenoids in determining their antimicrobial activity. Flavour and Fragrance Journal, 14: 322-332.

Khaosaad T., Vierheilig H., ZitTerl-Eglseer K., and Novak J., 2006 - Arbuscular mycorrbiza increases the content of essential oils in oregano (Origanum sp., Lamiaceae). Mycorrhiza, 16: 443-446.

Javanmardi J., Stushnoff C., Locke E., and VivANCO J. M., 2003 - Antioxidant activity and total phenolic content of Iranian Ocimum accessions. Food Chemistry, 83: 547-550.

Lewinsohn E., Ziv-Raz I., Dudai N., Tadmor Y., Lastochkin E., Larkov O., Chaimovitsh D., Ravid U., Putievsky E., Pichersky E., and ShoHAM Y., 2000 - Biosynthesis of estragole and methyl-eugenol in sweet basil (Ocimum basilicum L.). Developmental and chemotypic association of allylphenol O-methyltransferase activities. Plant Science, 160: 27-35.

Maritto M., Piccaglia R., and Giovanelli E., 1996 - Differences in essential oil composition of basil (Ocimum basilicum L.) Italian cultivars related to morphological characteristics. Journal of Agricultural and Food Chemistry, 44: 3926-3929.

Miele M., Dondero R., Ciarallo G., and Mazzei M., 2001 - Metbyleugenol in Ocimum basilicum L. cv. Genovese Gigante. Journal of Agricultural and Food Chemistry, 49: 517-521.

Nick P., 2000 - Control plant height. In: P. Nick (Ed) "Plant microtubules: potential for biotechnology", p. 1-23. Springer-Verlag, Heidelberg.

Pascual-Villalobos M. J., and Ballesta-Acosta M. C., 2003 - Chemical variation in an Ocimum basilicum germplasm collection and activity of the essential oils on Callosobruchus maculatus. Biochemical Systematics and Ecology, 31: 673-679.

Sangwan N., Verman B., Verma K., and Dhindsa K., 1990 - Nematocidal activity of some essential plant oils. Pesticide Science 28: 331-335.

SMith S. E., and ReAd D. J., 1997 - Mycorrbizal symbiosis. $2^{\text {nd }}$ edn. Academic Press, London. 
Torelli A., Trotta A., Acerbi L., Arcidiacono G., Berta G., and Branca C., 2000 - IAA and ZR content in leek (Allium porrum L.) as influenced by $P$ nutrition and arbuscular mycorrbizae, in relation to plant development. Plant and Soil, 226: 29-35.

Trotta A., Varese G. C., Gnavi E., Fusconi A., SAMPò S., and BerTA G., 1996. Interactions between the soilborne root pathogen Phytophthora nicotiane var. parasitica and the arbuscular mycorrbizal fungus Glomus mosseae in tomato plants. Plant Soil, 185: 199-209.

Trouvelot A., Kough J. L., and Gianinazzi-Pearson V., 1986 - Mesure du taux de mycorrbization VA d'un système radiculaire.Recherche de méthodes d'estimation ayant une signification fonctionelle. In: V. Gianinazzi-Pearson and S. Gianinazzi (Eds) "Physiological and genetical aspects of mycorrhizae”, p. 217-221. INRA, Paris.
Vogler H., Caderas D., Mandel T., and KuhleMEIER C., 2003 - Domains of expansin gene expression define growth regions in the shoot apex of tomato. Plant Molecular Biology, 53: 267-272.

Wan J., Wilcock A., and Covertry M. J., 1998 The effect of essential oil of basil on the growth of Aeromonas hydrophila and Pseudomonas fluorescens. Journal of Applied Microbiology, 84: 152-158.

Wang J., Dudareva N., Bhakta S., Raguso R. A., and Pichersky E., 1997 - Floral scent production in Clarkia breweri (Onagraceae). II. Localization and developmental modulation of the enzyme S-adenosylL-methionine: (iso)-eugenol O-methyltransferase and phenylpropanoid emission. Plant Physiology, 114: 213-221.

Received November $30^{\text {th }}$ 2006; accepted January $30^{\text {th }} 2007$ 